\title{
Performance of Co/Graphite electrode from citrate bath as electrocatalyst for oxygen evolution reaction in alkaline fuel cells
}

\author{
Ahmed S. Essa ${ }^{1}$, Hesham S. Abdel-Samad ${ }^{2}$, Hamdy H. Hassan ${ }^{2}$ \\ 1 Basic Science Department, Marg High Institute For Engineering and Modern Technology \\ (MIE), El-Marg, Qalyubiyah, Egypt. \\ 2 Chemistry Department, Faculty of science, Ain-Shams University, Abbasia, Cairo, 11566, \\ Egypt
}

\begin{abstract}
:
Cobalt/graphite electrodes are prepared by potentiostaticelectrodeposition of cobalt from sulphate baths with and without citrate ions on graphite discs. The electrocatalytic activity of the prepared electrodes toward oxygen evolution reaction (OER) is investigated by cyclic voltammetry technique. The electrocatalytic activity increases by increasing the concentration of $\mathrm{Co}^{+2}$ ions in the electrodeposition bath up to $0.5 \mathrm{M}$. The $\mathrm{Co} / \mathrm{Graphite}$ electrode obtained from electrodeposition bath containing $0.5 \mathrm{M} \mathrm{Co}^{2+}$ and $0.5 \mathrm{M}$ citrate ions, Co-Cit/G, exhibits better catalytic activity toward OER than that obtained from citrate free baths. Greater stability of Co$\mathrm{Cit} / \mathrm{G}$ electrode is verified by a chronopotentiometric test.
\end{abstract}

\section{Key words}

Cobalet,Citrate,Chronoamperometry,Chronopotentiometry, Cyclic

Voltammetry, Oxygenevalution reaction

\section{Introduction:}

The global challenge for discovering sustainable and renewable energy sources as alternative to the irrecoverable fossil fuels has been grown up in the last two decades and might extend for the next two decades (i, ii ). Fuel cell technology provides a superlative approach adapted to resolve the current world crisis of the continual depletion of the unsustainable energy sources in terms of efficiency, environmental and economical compatibility. Recently, many intensive studies focused on the development of alkaline fuel cells (AFCs) (iii ,iv )through constructing high efficient and low cost electrocatalysts mostly for the correlated electrochemical reactions including oxygen reduction reaction (ORR) and/or water splitting reactions: oxygen evolution reaction (OER), and hydrogen evolution reaction (HER) ( ${ }^{\text {vviviiviii }}$-ix). Owing to, hydrogen creation from water splitting reactions is highly obstructed by the sluggish kinetics of the multistep 4-electron OER. Consequently, OER represents a severe drawback implementing a significant overpotential requirement for fuel cell applications (x, xi). Accordingly, there is a great necessity for fabricating highly efficient electrocatalysts of low overpotentialtoovercome this energy barrier.

*Corresponding author: Dr.Ahmedessa@gmail.com 
Basically; the electrocatalysts made up from noble-metals, such as Pt\&Pd, regardless of their fair catalytic activity for OER, are the topmost stable fuel cell electrodes in all $\mathrm{pH}$ values $\left({ }^{\text {xii_ }}{ }^{x i i x i v x v}\right)$. Besides, iridium dioxide, and ruthenium dioxide are inordinate examples for high performance electrocatalysts with low overpotential and Tafel slope toward OER, particularly in acidic media $\left({ }^{\mathrm{xvi}}\right)$. However, these materials cannot be utilized economically, since their highly cost and scarcity hinder the marketable application of fuel cells ( ${ }^{\text {xii }}{ }_{-}^{\text {xviixix }}$ ). The most recent researches are interested in exchanging expensive noble metals and/or rare based materials used as fuel cell electrodes with non-precious and more earth abundant compounds $\left({ }^{\mathrm{xx}}-{ }^{\mathrm{xxixxii}}\right)$. For instance, transition metal-based materials, particularly nickel, cobalt and manganese oxides have been considered as hopeful alternatives due to their low price and high stability ( ${ }^{\mathrm{xxiii}}$ xxivxxvxxvixxviixxviiixxixxxxxxxi). Yet, these reported compounds have relatively high overpotential, and poor catalytic activity, toward OER compared with noble metal-based electrocatalysts(xxxii, xxxiii). More intensive efforts were carried out to expand the conductivity of these metal oxides and enhance their catalytic activity through diminishing their clusters into nano-sized structures.

For instance, the nanoparticles $\mathrm{Co}_{3} \mathrm{O}_{4}$ loaded onto highly conductive and large surface area carbon materials such as carbon nanotube and graphene, revealed greater catalytic performance with significant durability towards OER in neutral environments ( ${ }^{\text {xxxiv }}$ xxxvxxxvixxxvii $)$.

Additionally, citrate ion is considered among the most employed additives in electrodeposition baths $\left({ }^{\mathrm{xx} x \text { viii }}\right)$. It has been extremely utilized as strong complexing agent to several metals and alloys, for instance, nickel, cobalt copper, and iron (xxxviii- ${ }^{\text {xxxixxlxlixlii }}{ }^{\text {). Citrate }}$ is playing an important role in enhancing the electrodeposition of such metals by forming some polymeric species that block the electrode active sites responsible for hydrogen evolution reaction $\left({ }^{x l i i i}\right)$. It has been reported that cobalt citrate complex species controlled the morphology of the cobalt deposit and its nanostructure size $\left({ }^{\mathrm{xliv}},{ }^{\mathrm{xlv}}\right)$. More recently, the results of Frank and Sumodjo study $\left({ }^{x l v i}\right.$ ), showed that the electro-crystallization kinetics of Co deposited from citrate baths follows an instantaneous nucleation mechanism; and is independent on the $\mathrm{pH}$ and the applied potential.

Some valued reviews denoted the most recommended standard protocols for analyzing activity and stability of the well-intentioned electrocatalyst toward OER ( ${ }^{\text {xlvii }}{ }^{\text {xlviii }}$ ). For instance, Tahir et al (xlvii) suggested to plot the overpotential measured at current density $10 \mathrm{~mA} \mathrm{~cm}^{-2} \&$ $\mathrm{t}=0$ (in $\mathrm{x}$-axis) versus the overpotential obtained at current density $10 \mathrm{~mA} \mathrm{~cm}^{-2} \& \mathrm{t}=10 \mathrm{~h}$ (y-axis). Any material lies in the range of $400-500 \mathrm{mV}$ from $\mathrm{x}$-axis or $\mathrm{y}$-axis is considered as good OER catalyst; while the material lies in the range $300-400 \mathrm{mV}$ as brilliant catalyst. Only few materials lie (and stay after 10 hours) in the range of 200-300 mV. Consequently, they well-thought-out the ideal catalysts for OER applications in the literature.McCroryetal, (xlviii) declared a protocol to determine the short term electrocatalytic stability by holding the catalyst material at current density of $10 \mathrm{~mA} \mathrm{~cm}^{-2}$ for $2 \mathrm{~h}$ and measuring the operating potential as a function of time while rotating at a constant rotation rate of $1600 \mathrm{rpm}$. Additionally, measuring the onset potential is very important factor in evaluating the electrocatalytic activity toward OER.

In this work, cobalt is electrodeposited chronoamperometry on stationary or while rotating graphite discs from cobalt sulfate bath in absence and presence of equimolar concentration of 
citrate ions. the electrochemical responses toward OER and ORR of all prepared electrodes in $1 \mathrm{M}$ $\mathrm{NaOH}$ solution are evaluated using cyclic voltammetry. Tafel lines of the most active electrodes are analyzed to compare their activity toward OER. Additionally, the stability are evaluated chronopotentiometry while holding electrode at current density of $10 \mathrm{~mA} \mathrm{~cm}{ }^{-2}$ for $2 \mathrm{~h}$, for benchmarking our catalyst performance against the published ones ( $\left.{ }^{\text {xlvii }}, x l v i i i\right)$.

\section{Experimental:}

All electrolyte solutions were prepared from analytical grade chemicals and doubly distilled water. All experiments were done in three necked double jacket electrochemical cell. The working electrode was a Graphite rode (provided from EG\&G). This graphite rode was cut into discs form of $1 \mathrm{~cm}$ height and embedded in a TEFLON holder to offer an apparent geometrical surface area of $0.2826 \mathrm{~cm}^{2}$. The counter electrode was a platinum wire electrode. All potentials were recorded against saturated $\mathrm{Ag} \mid \mathrm{AgCl}$ reference electrode. Polishing of the working electrode with emery papers of 280 to 1000 grades was done until a smooth electrode surface was obtained, followed by rinsing with distilled water prior to each run. A fresh solution maintained at room temperature $\left(25 \pm 1^{\circ} \mathrm{C}\right)$ and newly polished electrode is used with each experiment. The measurements were done just after connecting the three electrodes and immersing the working electrode in the electrolyte. All electrochemical measurements were done using a reference 1000 Gamry electrochemical workstations provided with full software package.

The working electrodes were prepared by the potentiostatic electrodeposited at $-1.1 \mathrm{~V}$ from various $\mathrm{CoSO}_{4}$ solutions of concentration range $(0.01-0.8 \mathrm{M})$ and $(\mathrm{pH}=5.7 \pm 0.1)$ without and with $(0.2-0.5 \mathrm{M})$ sodium citrate $\left(\mathrm{Na}_{3} \mathrm{C}_{6} \mathrm{H}_{5} \mathrm{O}_{7} .2 \mathrm{H}_{2} \mathrm{O}\right)$ graphite discs for $600 \mathrm{~s}$.

Two classes of electrodes were prepared. The first class of electrodes were deposited on stationary graphite disk electrodes and nominated as SD-Co/G and SD-Co-Cit/G. The other class of electrodes were prepared on a $1600 \mathrm{rpm}$ rotating graphite discs and named RD-Co/G and RDCo-Cit/G. Table I, displays the prepared electrode symbols and their preparation conditions. The last class is investigated to demonstrate the extent of competition between Co deposition and ORR occurred simultaneously in the studied potential region. 
Table (I): Symbols for the prepared electrodes and their preparation conditions

\begin{tabular}{|c|l|}
\hline Electrode symbol & \multicolumn{1}{|c|}{ preparation conditions } \\
\hline $\mathrm{G}$ & bare graphite \\
\hline $\mathrm{SD}-\mathrm{Co}_{(\mathrm{x})} / \mathrm{G}$ & $\begin{array}{l}\text { electrodeposited cobalt on stationary graphite disk from bath } \\
\text { containing } \mathrm{x} \text { mole } \mathrm{Co}^{+2} \text { solution. }\end{array}$ \\
\hline $\mathrm{SD}-\mathrm{Co}-\mathrm{Cit} / \mathrm{G}$ & $\begin{array}{l}\text { electrodeposited cobalt on stationary graphite disk from bath } \\
\text { containing equimolar concentration of citrate solution. }\end{array}$ \\
\hline $\mathrm{RD}-\mathrm{Co}_{(\mathrm{x})} / \mathrm{G}$ & $\begin{array}{l}\text { electrodeposited cobalt on 1600 rpm rotated graphite disk from } \\
\text { bath containing x mole } \mathrm{Co}^{+2} \text { solution. }\end{array}$ \\
\hline $\mathrm{RD}-\mathrm{Co}-\mathrm{Cit} / \mathrm{G}$ & $\begin{array}{l}\text { electrodeposited cobalt on } 1600 \mathrm{rpm} \text { rotated graphite disk from } \\
\text { bath containing equimolar concentration of citrate solution. }\end{array}$ \\
\hline
\end{tabular}

The electrochemical responses of the prepared electrodes were recorded using cyclic voltammetry technique while $1600 \mathrm{rpm}$ rotation, Co/G-R \& Co-Cit/G-R electrodes, or through stationary electrodes, $\mathrm{Co} / \mathrm{G}-\mathrm{S} \& \mathrm{Co}-\mathrm{Cit} / \mathrm{G}-\mathrm{S}$, in $1 \mathrm{M} \mathrm{NaOH}$ solution from $-1.0 \mathrm{~V}$ to $1.2 \mathrm{~V}$ with a scan rate of $10 \mathrm{mV} \cdot \mathrm{s}^{-1}$.

\section{Results and Discussions:}

\subsection{Potentiodynamic polarization curves}

Fig (1a) shows anodic potentiodynamic spans at $10 \mathrm{mV} . \mathrm{s}^{-1}$ in $1 \mathrm{M} \mathrm{NaOH}$ solution for bare graphite stationary electrode, GS, and $1600 \mathrm{rpm}$ rotating graphite electrode GR, (curves 1 and 2). Recently, we studied the various parameters governing the OER over the graphite surface in alkaline medium (xlix). In this work we emphasized the relation between the structure of the surface function groups (SFG) of the graphite surface and its activity towards the OER and ORR on its surface. We suggested two types of the (SFG); easily oxidized carboxylates, and phenolates groups E-OxSFGs and more difficult oxidized edge and basal hydroxyl groups D-OxSFGs. The anodic span of the graphite surface, curves 1 and 2 , is void of anodic peaks till the onset potential of the OER, at this potential, a sufficient amount of oxygen is produced. Part of the produced oxygen, the inner (inherent) oxygen, is proved to be captured into the graphite surface in the form of oxidized graphite functional groups (OxSFG), adsorbed and/or trapped oxygen within the graphite pores. Moreover, the excess part of the produced oxygen (outer $\mathrm{O}_{2}$ ) is dissolved in the electrolyte (xlix). The higher currents observed of the OER upon rotating the electrode, curve 2, could be explained in terms of liberation of the graphite pores from inner $\mathrm{O}_{2}$ trapped within the pores. On the other hand, the cathodic reverse spans of the above-mentioned electrodes represented in Fig. (1b), curves 1 and 2, shows the previously observed cathodic peak CI at 0.35 $\mathrm{V}$ which attributed to the reduction of the D-OxSFGs. 
At more cathodic potentials, the oxygen reduction reaction, ORR, current plateaus PI and PII are recorded at -0.3 and $-0.75 \mathrm{~V}$, respectively. The diminish of PI and PII currents upon rotating the electrode, Fig. (1b) curves 1 and 2, confirms the above suggestion that electrode rotation liberates the graphite pores from the trapped inner $\mathrm{O}_{2}$. Moreover, the appearance of PI and PII plateaus for stationary electrode (GS) reflects the saturation of the electrode vicinity with $\mathrm{O}_{2}$ which contradict the known diffusion-controlled nature of the ORR. Consequently, the appearance of PI and PII plateaus in this condition could be ascribed to the reduction of the adsorbed or trapped inner oxygen rather than the dissolved outer $\mathrm{O}_{2}$ (xlix). The inner (inherent) oxygen was found to be reduced mainly through the more efficient 4-electron path way while the outer oxygen be reduced mostly via a lower efficient 2 - electron pathway.

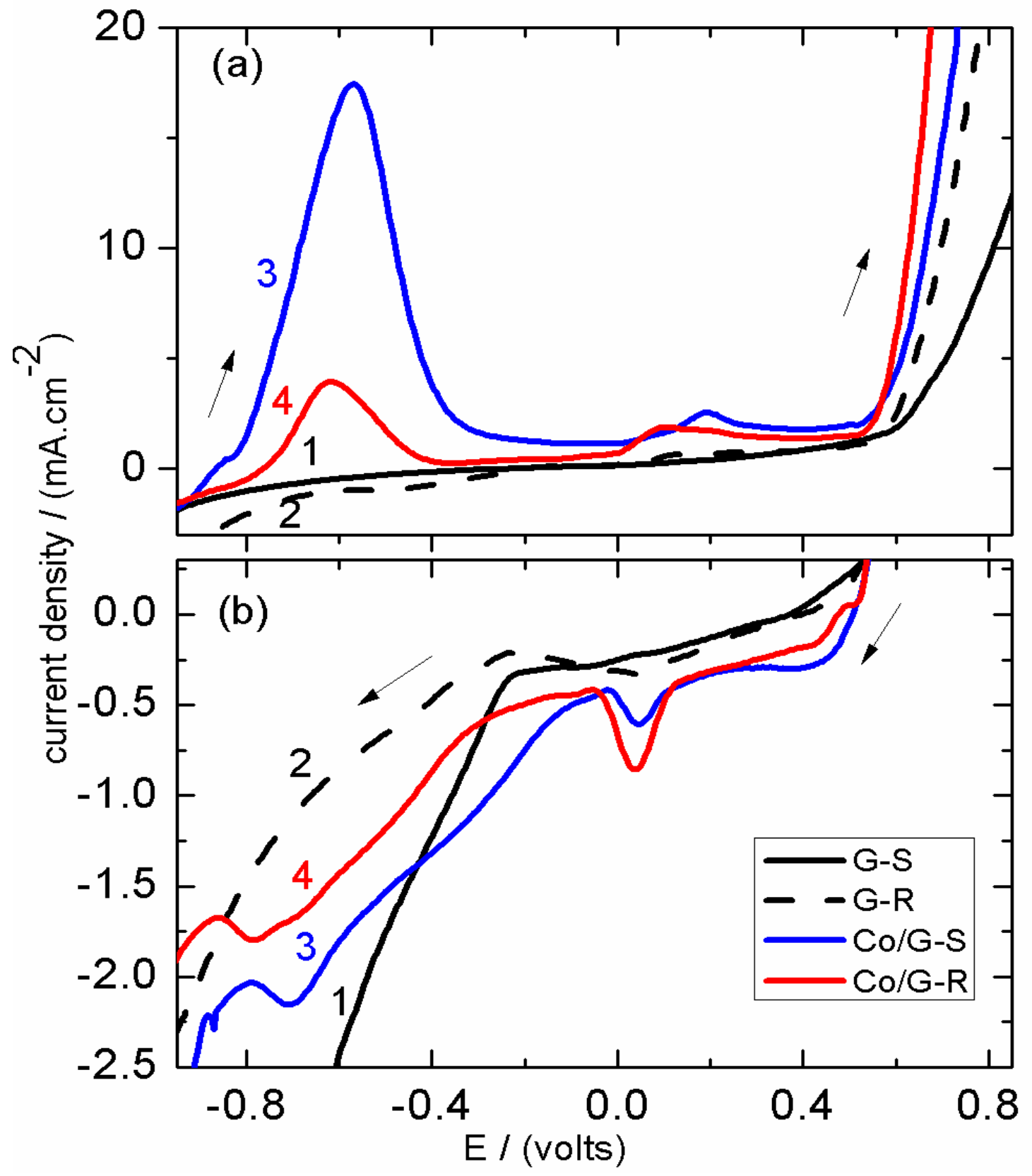


Fig. 1: Anodic (a) and cathodic (b) potentiodynamic spans for a stationary GS (curve 1, black solid line), $1600 \mathrm{rpm}$ rotating GR (curve 2, black dashed line), staionary RD-Co $(0.2) / G$ $S$ and $1600 \mathrm{rpm}$ rotating $\mathrm{RD}-\mathrm{Co}_{(0.2)} / \mathrm{G}-\mathrm{R}$ electrodes (curves 3,4 , blue and red lines respectively) at scan rate $10 \mathrm{mV} . \mathrm{s}^{-1}$ in $1 \mathrm{M} \mathrm{NaOH}$ solution.

On the other hand, the anodic voltammogram of the stationary cobalt electrode (RD$\mathrm{Co}_{(0.2)} / \mathrm{G}-\mathrm{S}$ ) is characterised by the presence of at least four anodic peaks prior to the OER, Fig. (1a) (curve 3). A small anodic shoulder A1 is observed at $-0.9 \mathrm{~V}$. This shoulder may be attributed to oxidation of deposited Co metal to a $(+\mathrm{I})$ oxidation state which is better known for cobalt than for any other element of the first transition series except copper $\left({ }^{1}\right)$. Earlier investigation of the electrocatalyticbehaviour of cobalt proposed the formation of $\mathrm{Co}(\mathrm{I})$ hydrous oxide species, $\left[\mathrm{Co}\left(\mathrm{H}_{2} \mathrm{O}\right)_{\mathrm{n}}\right]_{\text {ads }}^{+1}$, which acts as a mediator in electrocatalysis. These species were proposed to activate the oxidation of the solution species prior to the $\mathrm{Co} / \mathrm{Co}(\mathrm{OH})_{2}$ peak potential (li).

According to Pourbaix diagram of cobalt-water system at $25{ }^{\circ} \mathrm{C}$, a variety of thermodynamically stable cobalt oxides and/or cobalt hydroxides could be formed in alkaline solutions (lii). The well-defined anodic peak A2, has previously been assigned to $\mathrm{Co} / \mathrm{Co}$ (II) transformation and the formation of $\mathrm{Co}(\mathrm{OH})_{2}$, and/or $\mathrm{CoO}\left({ }^{\text {liii }}\right)$.

The potential range of the anodic shoulder A1 and peak A2 is typically the range of the diffusion controlled cathodic ORR, Fig.1b. Consequently, the current in this range is the resultant of two components; anodic Co oxidations, $J_{C o / C o(I-I I)}$, and cathodic ORR, $J_{O R R}$.

$$
J_{A 1 / A 2}=J_{C o / C o(I-I I)}-J_{O R R}
$$

The disappearance of $\mathrm{A} 1$ and the diminish of peak currents of A2 with rotating the electrode, as displayed by curve 4 of Fig. (1a) for $\mathrm{RD}-\mathrm{Co}_{(0.2)} / \mathrm{G}-\mathrm{R}$, may be explained in terms of the enhancement of the sluggish diffusion controlled ORR and $\mathrm{J}_{\mathrm{ORR}}$ by rotating the electrode. Our earlier investigation of the ORR on $\mathrm{Zn}$ surface in neutral media manifests similar attitude (liv, lv). The passive film formed on the deposited Co beyond A2 has been supposed to be composed of an inner $\mathrm{CoO}$ layer and outer $\mathrm{Co}(\mathrm{OH})_{2}$, layer (liii). Similar peaks were previously observed in the potential range of A1-A2 in other works regarding Co electrodeposition(xlvi, lvilviilviiilixlx). The attribution of these peaks to the dissolution of different Co phases, hydrogenincluded metallic $\alpha$-cobalt (hexagonal) HCP phase and pure metallic $\beta$-cobalt (face-centered cube) FCC phase previously deposited (lvii, lx) and/or the HCP to FCC transition (lvi) was also proposed. Peaks A3 and A4 have been previously assigned to the electro-oxidation of $\mathrm{Co}$ (II) species, $\mathrm{CoO}$ and/or $\mathrm{Co}(\mathrm{OH})_{2}$, to $\mathrm{Co}_{3} \mathrm{O}_{4}$ and $\mathrm{CoOOH}$, respectively (lxi_lxiilxiii]. Moreover, a very small anodic hump is also observed after A4 and prior to the OER. It may be attributed to the formation of $\mathrm{Co}(\mathrm{IV})$ species, most likely $\mathrm{CoO}_{2}$. It is worth noting that, the peak currents of A1 A4 diminish greatly for the second and the subsequent cyclic voltammograms (Fig 2), where, these cycles commence with an already formed Co passivated surfaces. 


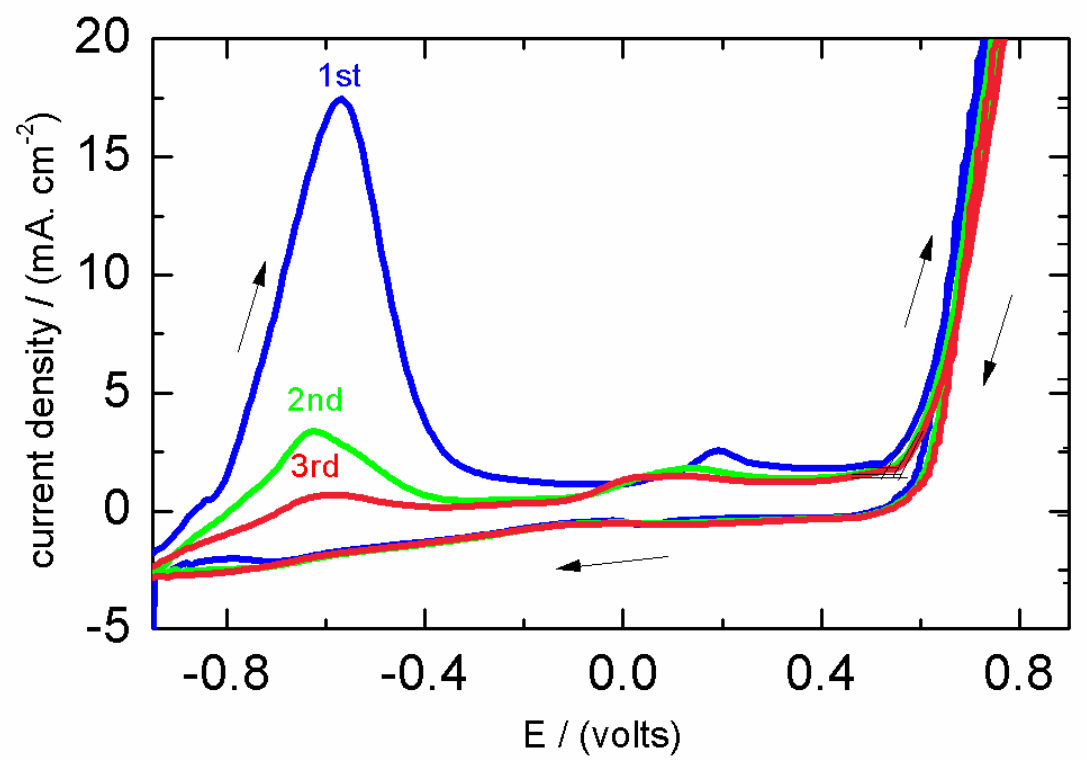

Fig (2) The first three successive cycles of potentiodynamic responses for $\mathrm{RD}-\mathrm{Co}(0.2) / \mathrm{G}-\mathrm{S}$ ,blue, light green and pink lines respectively, at scan rate $10 \mathrm{mV.s}-1$ in $1 \mathrm{M}$ NaOH solution.

Fig 3 illustrated the $2^{\text {nd }}$ cycle of the electrochemical responses at $10 \mathrm{mV} . \mathrm{s}^{-1}$ in $1 \mathrm{M} \mathrm{NaOH}$ obtained while $1600 \mathrm{rpm}$ rotation from $\mathrm{SD}-\mathrm{Co}_{(0.2)} / \mathrm{G}-\mathrm{R}$ and $\mathrm{RD}-\mathrm{Co}_{(0.2)} / \mathrm{G}-\mathrm{R}$ electrodes. Both electrodes exhibited almost the same features of electrochemical response discussed above. However, $\mathrm{RD}-\mathrm{Co}_{(0.2)} / \mathrm{G}-\mathrm{R}$ electrode is slightly more active toward both OER and ORR processes. 


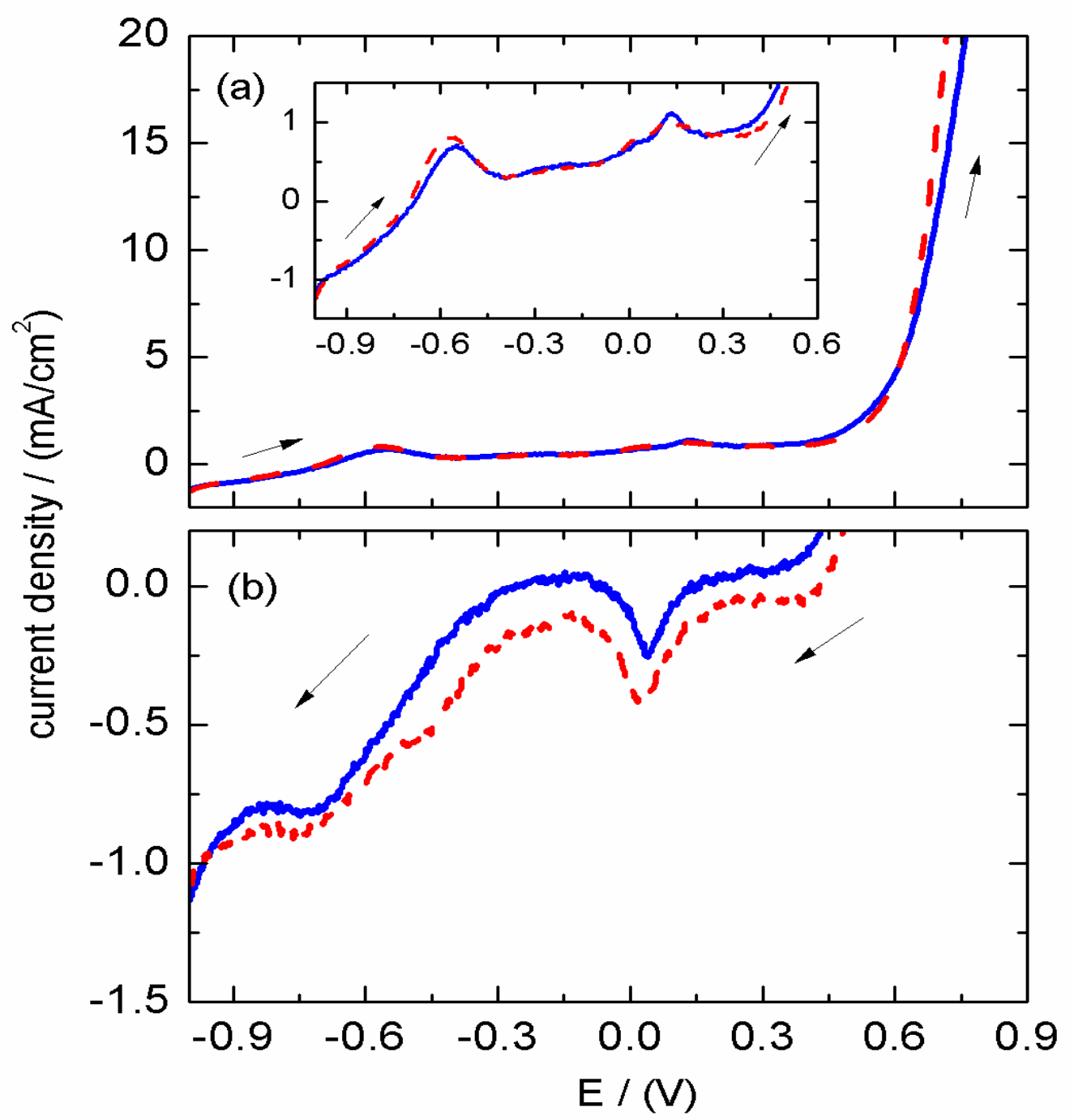

Fig.(3): 2nd cycles of anodic (a) \&cathodic (b) potentiodynamic spans of SD-Co $\mathrm{Co.2}_{(0.2)} / \mathrm{G}-\mathrm{R}$ (blue) \& RD-Co $\mathrm{o}_{(0.2)} / \mathrm{G}-\mathrm{R}$ (red) electrodes in $1 \mathrm{M} \mathrm{NaOH}$ at scan rate10 $\mathrm{mV} . \mathrm{sec}^{-1}$.The insert of Fig.(3a) is magnified region of (A1-A4) peaks.

\subsection{Oxygen evolution reaction (OER):}

Several parameters were recently used as a benchmark for comparing the electrochemical OER performance on different surfaces. Among these parameters, we adopt the OER onset potential (vs. RHE)andtheoverpotential required to achieve current density of $10 \mathrm{~mA} \cdot \mathrm{cm}^{-2}$ ( $\eta_{i=10 \mathrm{mA.cm}}{ }^{-2}$ )or as sometimes denoted as $\left(\eta_{t=0}\right)$ for benchmarking our catalyst performance against the published ones like the previously reported reviews. For instance, most of the earthabundant catalysts achieve $10 \mathrm{~mA} \mathrm{~cm}{ }^{-2}$ per geometric area current densities within a $0.07 \mathrm{~V}$ window between $\eta=\sim 0.360-0.430 \mathrm{~V}$ (xlviii).

For comparison, IrO achieves $10 \mathrm{~mA} \mathrm{~cm}{ }^{-2}$ current densities for OER at overpotentialsof $\eta=0.32$ $\pm 0.04 \mathrm{~V}$ in $1 \mathrm{M} \mathrm{NaOH}$. 
The $\mathrm{E}^{\mathrm{o}}$ value of OER (vs. RHE) at $\mathrm{pH} 14$ is calculated from the following equation:

$$
\begin{gathered}
\mathrm{E}_{\text {OER }}^{\mathrm{o}}=1.23-0.059 \mathrm{pH}=0.195 \mathrm{~V} \\
\eta_{\mathrm{to}}=\mathrm{e}_{\mathrm{i}=10}-\mathrm{E}_{\text {OER }}^{\mathrm{o}}
\end{gathered}
$$

The $1600 \mathrm{rpm}$ rotation rate is sufficiently fast to aid in product removal and limit bubble formation from evolved $\mathrm{O}_{2}$ at the electrode surface.

Synergetic effects between the graphitic support and Co oxide catalysts towards OER and ORR is very interesting phenomenon to be study. Inspection of the curves of Fig. 1A shows rapid increase in the current density beyond the potential range of A4 associated with a naked eye recognised gas evolution. The catalytic action of the formed $\mathrm{Co}$ (III) species (specially $\mathrm{CoOOH}$ ) is manifested as we compare the OER onset potentials, $\mathrm{E}_{\mathrm{OER}}$, and $\boldsymbol{\eta}_{\mathbf{t} \mathbf{0}}$ of the bare GE, curves 1 and 2 , with their values observed for prepared $\mathrm{Co} / \mathrm{G}$ electrodes and recorded them in Table II.

Table (II): Overpotential at $10 \mathrm{~mA} \cdot \mathrm{cm}^{-2}$ and OER parameters of the first cycle of potentiodynamic responses at scan rate $10 \mathrm{mV}^{-1}{ }^{-1}$ in $1 \mathrm{M} \mathrm{NaOH}$ solution for bare graphite, RD-Co $0_{(0.2)} / G R$ and the first three successive cycles of RD-Co $\mathbf{O}_{(0.2)} / G S$ electrode.

\begin{tabular}{|c|c|c|c|c|}
\hline Electrode & $\mathrm{E}_{\mathrm{I}=10 \mathrm{~mA} / \mathrm{cm}}{ }^{2}$ & $\eta_{\mathrm{t} 0}$ & OER $_{\text {onset }}$ & $\eta_{\text {OERonset }}$ \\
\hline $\mathrm{G}-\mathrm{S}$ & $0.811 \mathrm{~V}$ & $0.616 \mathrm{~V}$ & $0.644 \mathrm{~V}$ & 0.449 \\
\hline $\mathrm{G}-\mathrm{R}$ & $0.697 \mathrm{~V}$ & $0.502 \mathrm{~V}$ & $0.590 \mathrm{~V}$ & 0.395 \\
\hline $\begin{array}{c}\mathrm{RD}-\mathrm{Co}_{(0.2)} / \mathrm{GS} \\
\left(1^{\mathrm{st}} \mathrm{cycle}\right)\end{array}$ & $0.662 \mathrm{~V}$ & $0.467 \mathrm{~V}$ & $0.583 \mathrm{~V}$ & 0.388 \\
\hline $\begin{array}{c}\mathrm{RD}-\mathrm{Co}_{(0.2)} / \mathrm{GS} \\
\left(2^{\text {nd }} \mathrm{cycle}\right)\end{array}$ & $0.677 \mathrm{~V}$ & $0.482 \mathrm{~V}$ & $0.614 \mathrm{~V}$ & 0.419 \\
\hline $\begin{array}{c}\mathrm{RD}-\mathrm{Co}_{(0.2)} / \mathrm{GS} \\
\left(3^{\text {rd }} \mathrm{cycle}\right)\end{array}$ & $0.684 \mathrm{~V}$ & $0.489 \mathrm{~V}$ & $0.617 \mathrm{~V}$ & 0.422 \\
\hline $\mathrm{RD}-\mathrm{Co}_{(0.2)} / \mathrm{GR}$ & $0.627 \mathrm{~V}$ & $0.432 \mathrm{~V}$ & $0.555 \mathrm{~V}$ & 0.360 \\
\hline
\end{tabular}

\subsection{Effect of Cobalt ion concentration:}

Fig. 4 shows the effect of cobalt ion concentration in the electrodeposition bath on the electrochemical characteristic responses of $\mathrm{RD}-\mathrm{Co}_{(\mathrm{x})} / \mathrm{G}-\mathrm{R}$ electrodes. As the $\mathrm{Co}^{+2}$ ion concentration increases, both anodic and cathodic peaks enlarged up to $0.5 \mathrm{M}$ of $\mathrm{Co}^{2+}$ concentration. Further increasing of cobalt ion concentration leads to diminishing of both anodic, and cathodic peaks. Moreover, both overpotential at $10 \mathrm{~mA} \cdot \mathrm{cm}^{-2}\left(\eta_{\mathrm{t} t}\right)$ and the onset of OER and decreases by increasing the Co ion concentration up to $0.5 \mathrm{M} \mathrm{Co}^{+2}$ and hence the current density of anodic peaks (Table III). 


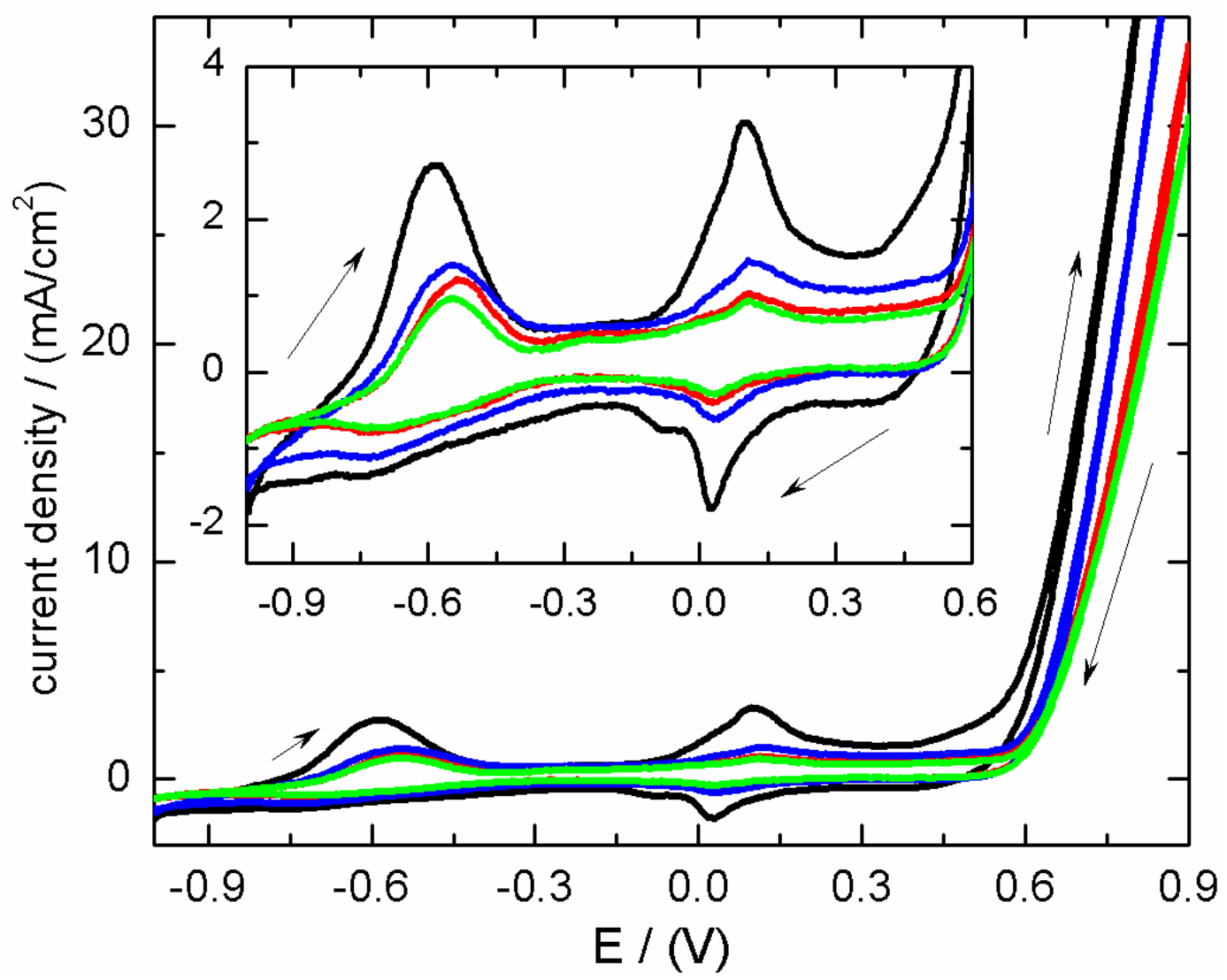

Fig. (4): The 2nd cycle potentiodynamic responses for $\mathrm{RD}-\mathrm{Co}_{(\mathrm{x})} / \mathrm{G}-\mathrm{R}$ electrodes in $1 \mathrm{M}$ $\mathrm{NaOH}$ solution at $10 \mathrm{mV} \cdot \mathrm{s}^{-1} ; \mathrm{x}=$ the concentration of $\mathrm{Co}^{2+}$ in the electrodeposition bath, $0.01 \mathrm{M}$ (light green), $0.2 \mathrm{M}$ (blue), $0.5 \mathrm{M}$ (black) and $0.8 \mathrm{M}$ red. The insert illustrates magnified $(-1$ to $0.6 \mathrm{~V})$ region.

Table (III): Overpotential at $10 \mathrm{~mA} \cdot \mathrm{cm}^{-2}$ of the $2^{\text {nd }}$ cycle of potentiodynamic responses at scan rate $10 \mathrm{mV} . \mathrm{s}^{-1}$ while $1600 \mathrm{rpm}$ rotating in $1 \mathrm{M} \mathrm{NaOH}$ solution for RD-Co(x)/GR electrodes

\begin{tabular}{|c|c|c|}
\hline electrode & $\mathrm{E}_{\mathrm{I}=10 \mathrm{~mA} / \mathrm{cm}^{2}}$ & $\eta_{\mathrm{t} 0}$ \\
\hline $\mathrm{RD}-\mathrm{Co}_{(0.1)} / \mathrm{GR}$ & 0.69 & 0.495 \\
\hline $\mathrm{RD}^{-\mathrm{Co}_{(0.2)} / \mathrm{GR}}$ & 0.727 & 0.532 \\
\hline $\mathrm{RD}-\mathrm{Co}_{(0.5)} / \mathrm{GR}$ & 0.647 & 0.452 \\
\hline $\mathrm{RD}-\mathrm{Co}_{(0.8)} / \mathrm{GR}$ & 0.718 & 0.523 \\
\hline
\end{tabular}




\subsection{Effect of Citrate ion:}

Fig. 5 shows that RD-Co-Cit/G-R electrode displays a slight increase in the electrocatalytic activity toward the OER than that obtained from RD-Co/G-R electrode. It was early reported that the Co electrodeposition from baths containing citrate ions takes place through an instantaneous nucleation particularly in the feebly acidic conditions of this study (xlvi). This is attributed to the large size of Co (II) citrate complexes, which may delay the surface diffusion of these massive species towards more stable active sites, and nucleation occurs instantly after the electrodeposition potential is applied.Subsequently, a slow growth of Co nuclei occurs on less significant number of active sites and, after their coalescence, a more uniform metallic cobalt film is formed.Otherwise, the cobalt deposited from no additive baths occurs with a fast-progressive nucleation on countless active sites (xliii).

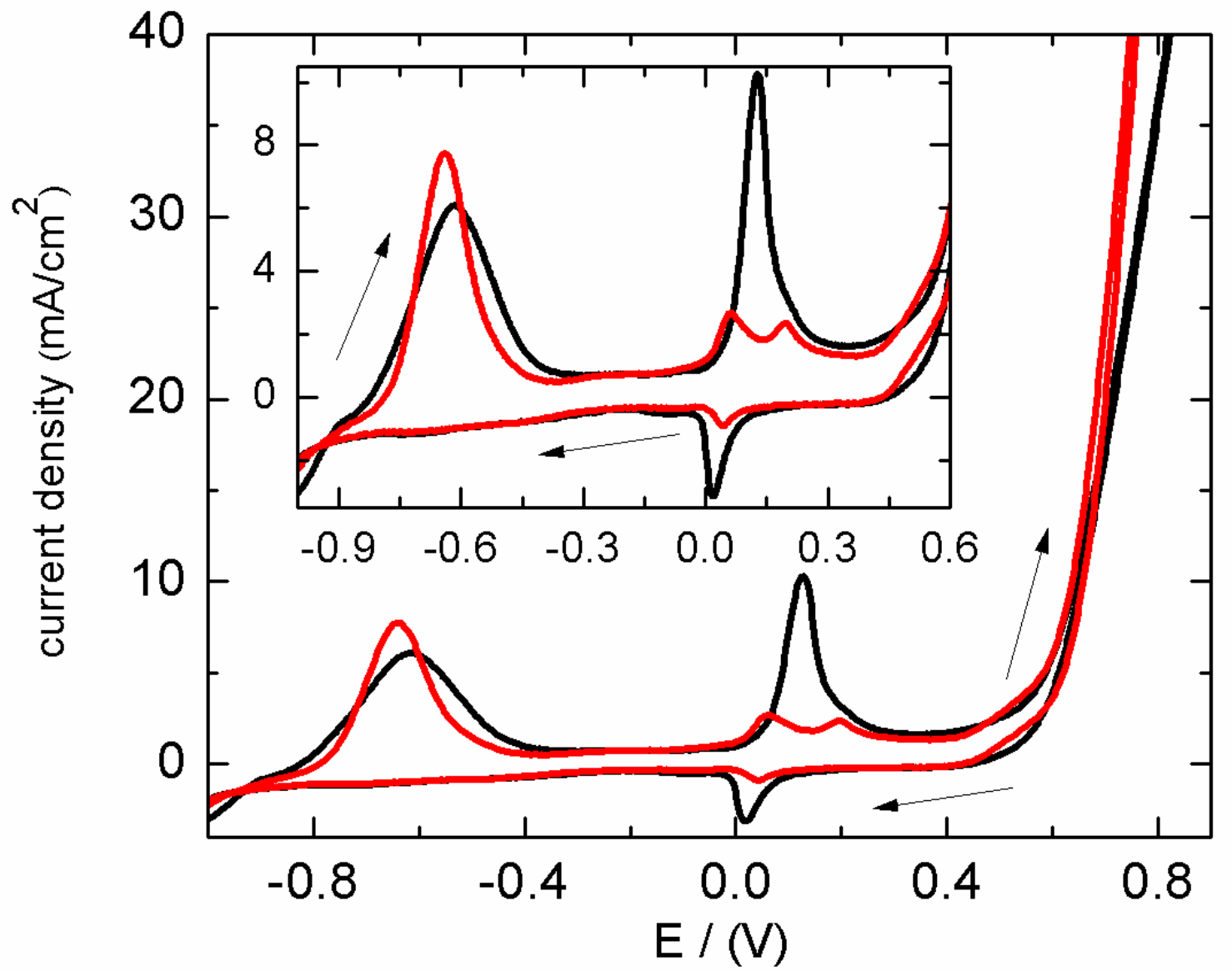

Fig. (5): The 1st. cycle potentiodynamic responses for $\mathrm{RD}-\mathrm{Co}_{(0.5)} / \mathrm{G}-\mathrm{R}$ (black), and RD$\mathrm{Co}_{(0.5)}-\mathrm{Cit}_{(0.5)} / \mathrm{G}-\mathrm{R}$ (red) electrodes while $1600 \mathrm{rpm}$ rotation in $1 \mathrm{M} \mathrm{NaOH}$ solution at $10 \mathrm{mV} . \mathrm{s}^{-1}$. The insert represents the magnified $(-1$ to $0.6 \mathrm{~V})$ region. 
Our obtained results shown in Fig. (5) confirm that the uniform cobalt film obtained while deposition from citrate bath may account the enhanced electrocatalytic activity of RD-Co-Cit/GR electrode toward OER compared with that obtained by RD-Co/G-R electrode.

\section{Cyclic voltammetric Activation:}

The catalytic activity of RD-Co-Cit/G electrode is increased gradually through 30 successive potentiodynamic polarization and $1600 \mathrm{rpm}$ rotation in $1 \mathrm{M} \mathrm{NaOH}$ solution. Fig. 6 illustrates some selective cycles of the potentiodynamic polarization for RD-Co-Cit/G-R electrode in $1 \mathrm{M} \mathrm{NaOH}$ solution. Overpotentialat $10 \mathrm{~mA} \cdot \mathrm{cm}^{-2}$ of these selected cycles and their OER onset are listed in Table (IV). It is clear that the electrocatalytic activity towards OER enhances with the subsequent cycles.

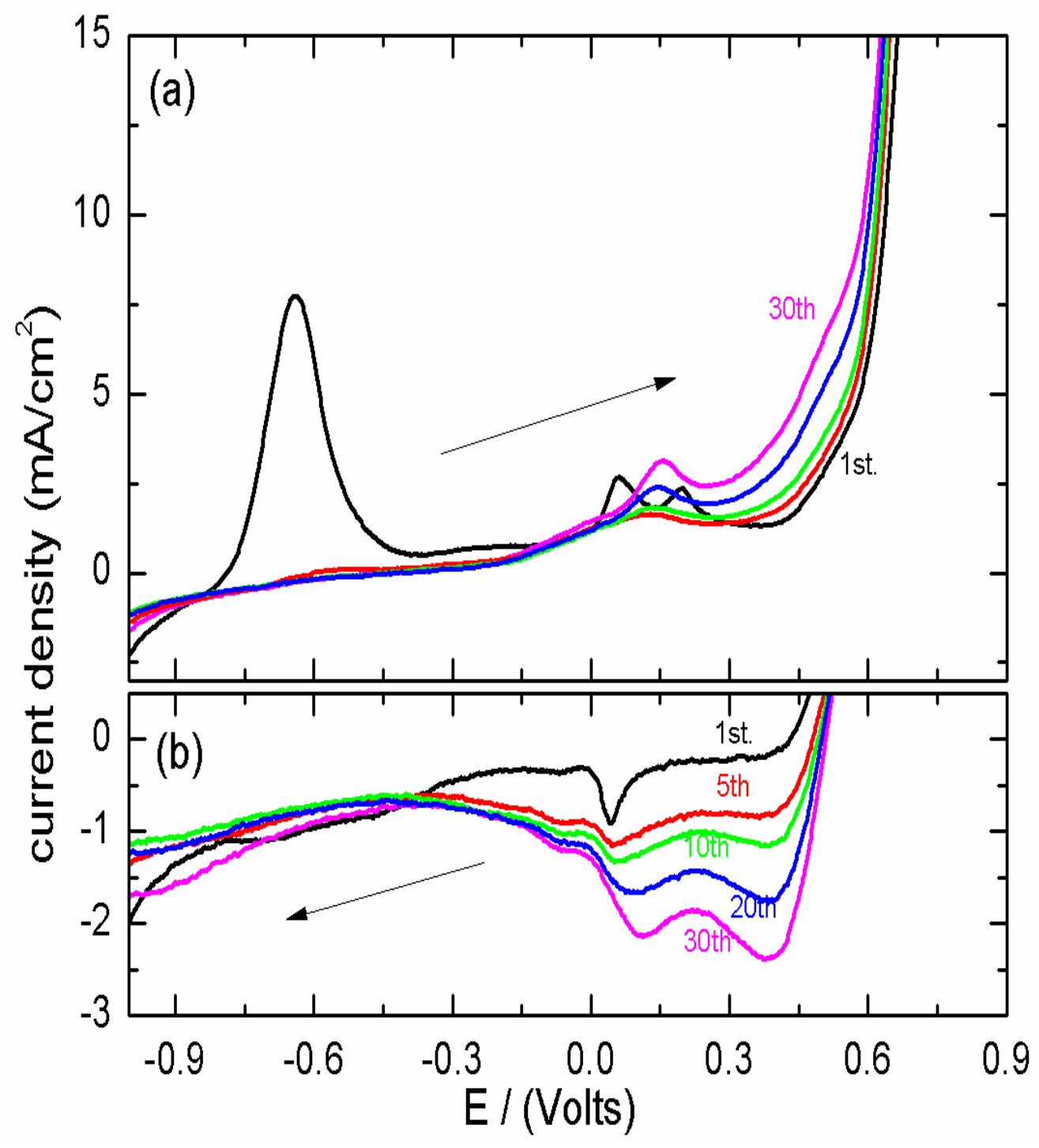


Fig. 6: Successive cycles of potentiodynamic (a) forward span and (b) backward span of the 1st, 5th, 10th, 20th and 30th cycle; black, red, green, blue and pink curves RD-Co-Cit/G-R electrode in $1 \mathrm{M} \mathrm{NaOH}$ at scan rate of $10 \mathrm{mV} . \mathrm{s}^{-1}$.

The OER potential region for the above-illustrated cycles is extensively studied and their corresponding Tafel lines are graphically represented in Fig.7 and its insert.

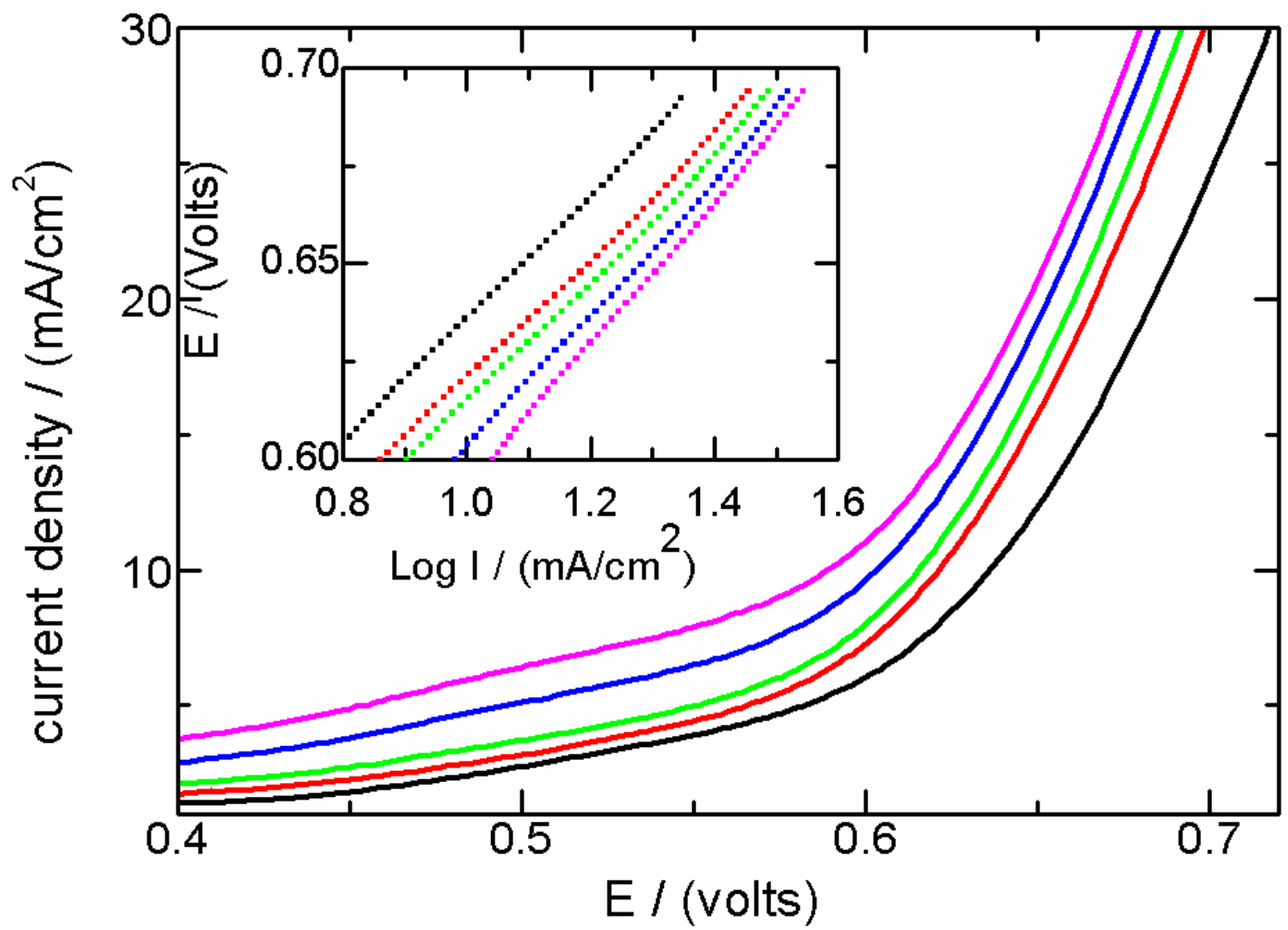

Fig. 7: Steady-state polarization of the 1st, 5th, 10th, 20th and 30th cycle; black, red, green, blue and pink curves respectively for the OER on RD-Co-Cit/GR electrode.

The insert represents their corresponding Tafel plots. 
Table (IV): Overpotential at $10 \mathrm{~mA} \cdot \mathrm{cm}^{-2}$ and OER parameters of some selected cycles of successive potentiodynamic responses at scan rate of $10 \mathrm{mV} \cdot \mathrm{s}^{-1}$ in $1 \mathrm{M} \mathrm{NaOH}$ solution for RD-Co $0_{(0.5)}-\mathrm{Cit}_{(0.5)} / \mathrm{G}$ electrode and their corresponding Tafel line parameters in OER potential region (slopes $(a)$, intercept $(b)$ and the exchange currents $\left.\left(i_{0}\right)\right)$ :

\begin{tabular}{|c|c|c|c|c|c|c|c|}
\hline \multirow[b]{2}{*}{$\begin{array}{c}\text { Cycle } \\
\text { number }\end{array}$} & \multirow[b]{2}{*}{$\begin{array}{c}\mathrm{E}_{\mathrm{I}=10 \mathrm{~mA} / \mathrm{c}} \\
\mathrm{m}^{2} \\
(\text { volts })\end{array}$} & \multirow[b]{2}{*}{$\begin{array}{c}\boldsymbol{\eta}_{\mathbf{t 0}} \\
(\text { volts })\end{array}$} & \multirow[b]{2}{*}{$\begin{array}{c}\text { OER }_{\text {onse }} \\
\mathbf{t} \\
\text { (volts) }\end{array}$} & \multirow[b]{2}{*}{$\begin{array}{c}\text { クOER } \\
\text { (volts) }\end{array}$} & \multicolumn{3}{|c|}{ Tafel line parameters } \\
\hline & & & & & $\begin{array}{c}\text { intercip } \\
\text { t } \\
\text { (a) }\end{array}$ & $\begin{array}{c}\text { slope } \\
\text { (b) }\end{array}$ & $\begin{array}{l}\text { Exchange } \\
\text { current }\left(\mathbf{i}_{\mathbf{0}}\right) \\
\qquad\left(\mathrm{mA} / \mathrm{cm}^{2}\right)\end{array}$ \\
\hline $1^{\text {st }}$ cycle & 0.636 & 0.441 & 0.602 & 0.407 & 0.477 & 0.159 & 0.0010 \\
\hline $5^{\text {th }}$ cycle & 0.621 & 0.426 & 0.581 & 0.386 & 0.467 & 0.154 & 0.0009 \\
\hline $10^{\text {th }}$ cycle & 0.615 & 0.42 & 0.576 & 0.381 & 0.458 & 0.157 & 0.0012 \\
\hline $20^{\text {th }}$ cycle & 0.603 & 0.408 & 0.572 & 0.377 & 0.432 & 0.171 & 0.0029 \\
\hline $30^{\text {th }}$ cycle & 0.589 & 0.394 & 0.567 & 0.372 & 0.409 & 0.183 & 0.0058 \\
\hline
\end{tabular}

As can be seen from the Tafel line parameters summarized in Table (IV); the values of both Tafel slope and exchange current of the tested electrode increase with the subsequent cycling in $\mathrm{NaOH}$ solution.

This implies that the electrocatalytic activity of RD-Co-Cit/G electrode enhances gradually towards OER by successive potentiodynamic polarization in alkaline medium.

\section{Electrocatalytic stability:}

The stability of two RD-Co-Cit/G electrodes, (fresh and after 30 cycles of potentiodynamic activation in $\mathrm{NaOH}$ solution), for the OER in $1 \mathrm{M} \mathrm{NaOH}$ solution were tested for two hours at constant current density as recommended by benchmark studies (xlviii). The potential-time response is shown in Fig. 8. 


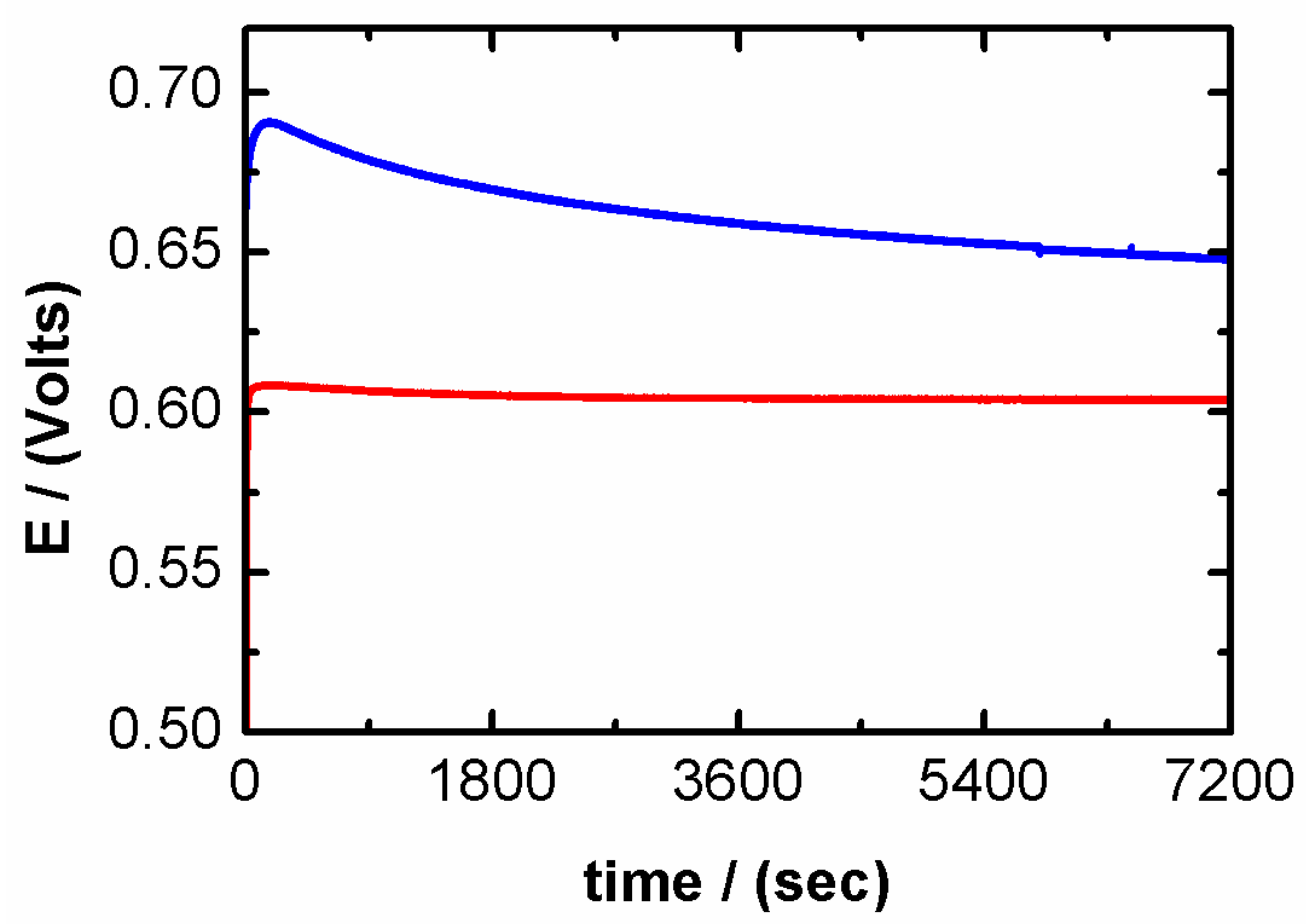

Fig. 8: Two hours stability test for fresh RD-Co-Cit/GR electrode (red curve) and after 30 cycles potentiodynamic response in $1 \mathrm{M} \mathrm{NaOH}$ (blue curve).

It is clear that, the potentials of activated electrode remain nearly constant within the two hours test period, indicating its superior stability for the OER in an alkaline medium.

\section{Conclusions:}

Many cobalt/graphite electrodes were successfully prepared via chronoamperometry deposition of cobalt from $\mathrm{Co}^{+2}$ bath with and without equimolar concentration of citrate ion on graphite substrate. The prepared electrode was evaluated as oxygen evolution reaction (OER) electrocatalyst. The presence of citrate ion in the electrodeposition bath favors the instantaneous nucleation of Co deposition rather than the progressive nucleation, leading to form a more uniform cobalt metal film on the graphite substrate. Therefore, the Cobalt/graphite electrode prepared from citrate bath displayed an enhanced electrocatalytic activity toward OER. Extra catalytic activity and prolonged stability were gained by Co-Cit/G electrode via successive potentiodynamic polarization in $\mathrm{NaOH}$ solution. The chronopotentiometry (potential-time), at constant current density stability test for $2 \mathrm{~h}$, showed a superior stability for OER in alkaline medium. 


\section{References:}

A. Aijaz, J. Masa, C. R.sler, W. Xia, P. Weide, A.J.R. Botz, R.A. Fischer, W. Schuhmann, M. Muhler, Angew. Chem. Int. Ed. 55 (2016) 4087-4091.

A. Bergmann, E. Martinez-Moreno, D. Teschner, P. Chernev, M. Gliech, J.F. de Araujo, T.

Reier, H. Dau, P. Strasser, Nat. Commun. 6 (2015) 8625.

Ahmed B. Soliman, Hesham S. Abdel-Samad, Sayed S. Abdel Rehim, Hamdy H. Hassan, Sci. Rep. 6, 22056; doi:10.1038/srep22056 (2016).

Ahmed B. Soliman, Hesham S. Abdel-Samad, Sayed S. Abdel Rehim, Mohamed A. Ahmed, Hamdy H. Hassan, Journal of Power Sources 325 (2016) 653-663.

A.B. Soto, E.M. Arce, M. Palomar-Pardavé, I. Gonzalez, Electrochim. Acta 41 (1996) 26472655.

A.C. Frank, P.T.A. Sumodjo, ElectrochimicaActa 132 (2014) 75-82.

Alan M.P. Sakita, Rodrigo Della Noce, Cecílio S. Fugivara and Assis V. Benedetti, Phys. Chem. Chem. Phys., 2016,18, 25048-25057

Allen J. Bard and Marye Anne Fox, Acc. Chem. Res.,1995,28(3), pp 141-145.

Bashyam, R.; Zelenay, P., Nature 2006, 443, 63-66.

C. Budischak, D. Sewell, H. Thomson, L. Mach, D.E. Veron, W. Kempton, Journal of Power Sources 225 (2013) 60-74.

Charles C. L. McCrory, Suho Jung, Jonas C. Peters and Thomas F. Jaramillo, J. Am. Chem. Soc. 2013, 135, 16977-16987.

C.-H. Kuo, W. Li, L. Pahalagedara, A.M. El-Sawy, D. Kriz, N. Genz, C. Guild, T. Ressler, S.L. Suib, J. He, Angew. Chem. Int. Ed. 54 (2015) 2345-2350.

Chen, X.; Wu, G.; Chen, J.; Chen, X.; Xie, Z.; Wang, X., J. Am. Chem. Soc. 2011, 133, 36933695.

E. Gomez, A. Labarta, A. Llorente, E. Vallés, J. Electroanal. Chem. 517 (2001) 63-68.

E.J. Podlaha, D. Landolt, J. Electrochem. Soc. 144 (1997) 1672-1680.

F.A. Frame, T.K. Townsend, R.L. Chamousis, E.M. Sabio, T. Dittrich, N.D. Browning, F.E. Osterloh, J. Am. Chem. Soc. 133 (2011) 7264-7267.

F.A. Cotton, G. Wilkinson, Advanced Inorganic Chemistry, third ed., Interscience, New York, 1972. 
Fei, H.; Ye, R.; Ye, G.; Gong, Y.; Peng, Z.; Fan, X.; Samuel, E. L. G.; Ajayan, P. M. Tour, M. J., ACS Nano 2014, 8, 10837-10843.

F.M.Takata,P.T.A.Sumodjo, Electrochim.Acta52(2007) 6089-6096.

G.S. Hutchings, Y. Zhang, J. Li, B.T. Yonemoto, X. Zhou, K. Zhu, F. Jiao, J. Am. Chem. Soc. 137 (2015) 4223-4229.

G. Wu, A. Santandreu, W. Kellogg, S. Gupta, O. Ogoke, H. Zhang, H.-L. Wang, L. Dai, Nano Energy 29 (2016) 83-110.

H. A. Gasteiger, S. S. Kocha, B. Sompalli, F. T. Wagner, Appl. Catal. B 56, 9 (2005)..

H. H. Hassan, Electrochim. Acta, 51, 5966-5972 (2006).

-H. H. Hassan, M. A. Amin, S. Gubbala, M. K. Sunkara, Electrochim. Acta, 52, 6929-6937 (2007).

H. Jin, J. Wang, D. Su, Z. Wei, Z. Pang, Y. Wang, J. Am. Chem. Soc. 137 (2015) 2688-2694.

Hubert A Gasteiger, N. M. Marković, Science 324, 48 (2009) Vol. 324, Issue 5923, pp. 48-49.

J. Zhang, Z. Zhao, Z. Xia, L. Dai, Nat. Nanotechnol. 10 (2015) 444-452.

J. Bao, X. Zhang, B. Fan, J. Zhang, M. Zhou, W. Yang, X. Hu, H. Wang, B. Pan, Y. Xie, Angew. Chem. Int. Ed. 54 (2015) 7399-7404.

J. Chivot, L. Mendoza, C. Mansour, T. Pauporté, M. Cassir, Corros. Sci., 50 (2008) 62-69.

J.-L. Shui, N.K. Karan, M. Balasubramanian, S.-Y.Li, D.-J. Liu, J. Am. Chem. Soc.134 (2012) $16654-16661$.

J. Rossmeisl, Z. W. Qu, H. Zhu, G. J. Kroes, J. K. Norskov, J. Electroanal. Chem. 607, 83 (2007).

K. Fominykh, P. Chernev, I. Zaharieva, J. Sicklinger, G. Stefanic, M. Doblinger, A. Muller, A. Pokharel, S. Bocklein, C. Scheu, T. Bein, D. Fattakhova-Rohlfing, ACS Nano 9 (2015) 51805188.

K. Kordesch, V. Hacker, J. Gsellmann, M. Cifrain, G. Faleschini, P. Enzinger, R. Fankhauser, M. Ortner, M. Muhr, R.R. Aronson, Journal of Power Sources 862000 162-165.

K.L. Nardi, N. Yang, C.F. Dickens, A.L. Strickler, S.F. Bent, Adv. Energy Mater. 5 (2015) 1500412.

L.D. Burke, M.M. Murphy, J. Electrochem. Soc. 138 (1991) 88-94. 
Lee, Y.; Suntivich, J.; May, K. J.; Perry, E. E.; Shao-Horn, Y., J. Phys. Chem. Lett. 2012, 3, 399404.

Mondal, A.; Jana, N. R., ACS Catal. 2014, 4, 593-599.

Meng C., Ling T., Ma T.Y., Wang H., Hu Z.P., Zhou Y., Mao J., Du X.W., Qiao S.Z., Advanced Materials, 2017, 29, 1604607.- M.C. Esteves, P.T.A. Sumodjo, J. Electrochem. Soc. 153 (2006) C540-C545.

M. Donten, Z. Stojek, H. Cesiulis, J. Electrochem. Soc. 150 (2003) C95-C98.

M. Huynh, C. Shi, S.J.L. Billinge, D.G. Nocera, J. Am. Chem. Soc. 137 (2015) 14887-14904.

Mei LengXiaolei Huang, Wen Xiao, Jun Ding, Binghai Liu, JunminXue, Yonghua Du, Nano Energy 33 (2017) 445-452.

Muhammad Tahir, Lun Pan, FaryalIdrees, Xiangwen Zhang, Li Wang, Zhong Lin Wang, Ji-Jun Zou, Nano Energy 37 (2017) 136-157.

M. T. M. Koper, J. Electroanal. Chem. 660, 254 (2011).

N.V. Myung, D.-Y.Park, B.-Y.Yoo, P.T.A. Sumodjo, J. Magn. Magn.Mater. 265 (2003) 189198.

O.BerkhL.Burstein, Y. Shacham-Diamand, E. Gileadi, J. Electrochem.Soc. 158 (2011) F85-F91.

R. Bertazzoli, D. Pletcher, Electrochim. Acta 38 (1993) 671-676.

R.-T. Wang, et al., J. Power Sources 217 (2012) 358-363.

S. Cherevko, S. Geiger, O. Kasian, N. Kulyk, J.-P. Grote, A. Savan, B.R. Shrestha, S. Merzlikin,

B. Breitbach, A. Ludwig, K.J.J. Mayrhofer, Catal. Today 262 (2016) 170-180.

S. Ma, L. Sun, L. Cong, X. Gao, C. Yao, X. Guo, L. Tai, P. Mei, Y. Zeng, H. Xie, R. Wang, J. Phys. Chem. C 117 (2013) 25890-25897.

S.S. Abd El Rehim, A.A. El Basosi and M.M. Osman, J. Electroanal. Chem., 348 (1993) 99-106.

S.S. Abd El Rehim, S.M. Abd El Wahaab, M.A.M. Ibrahim, M.M. Dankeria, J. Chem. Technol. Biotechnol. 73 (1998) 369-376.

T.R. Jayaraman, V.K. Venkatesan and H.V.K. Udupa, Electrochim. Acta, 20 (1975) 209.

T.R. Jayaraman, V.K. Venkatesan and H.V.K. Udupa, Proc. 14th Seminar on Electrochemistry, Karaikudi, India, November 1973 (1974) pp. 274-282; Chem. Abstr., 83 (1975) 161796x.

T.Y. Ma, S. Dai, M. Jaroniec, S.Z. Qiao, J. Am. Chem. Soc. 136 (2014) 13925- 13931. 
U. Eberle, R. von Helmolt, Energy Env. Sci., 3 (2010), pp. 689-699.

W.D. Chemelewski, H.-C.Lee, J.-F. Lin, A.J. Bard, C.B. Mullins, J. Am. Chem. Soc. 136 (2014) 2843-2850.

W.K. Behl and J.E. Toni, J. Electroanal. Chem., 31 (1971) 63.

Y. Dou, T. Liao, Z. Ma, D. Tian, Q. Liu, F. Xiao, Z. Sun, J. Ho Kim, S. Xue Dou, Nano Energy 30 (2016) 267-275.

Y. Kobayashi, M. Horie, M. Konno, B. Rodrيguez-GonzJlez, and L. M. Liz-MarzJn 7420-7425 (2003).

Y. Yamashita, M. Tada, M. Kakihana, M. Osada, K. Yoshida, J. Mater. Chem. 12 (2002) 17821786.

Y. Zhao, S. Chen, B. Sun, D. Su, X. Huang, H. Liu, Y. Yan, K. Sun, G. Wang, Sci. Rep. 5 (2015) 7629.

Z. Li, X.-Y. Yu, U. Paik, J. Power Sources 310 (2016) 41-46. 


\section{الملخص باللغة العربية}

أداء قطب الكوبالت / الجرافيت من حمام سيترات في عملية تحفيز كهربي electrocatalyst لتفاعل تصاعد الأكسجين في خلايا الوقود القلوية

\section{أحمد سيد عيسي 1 ، حمدي حسنين حسن2، ، هشام سمير عبدالصمد2}

1- قسم العلوم الاساسية ، المعهد العالي للهندسة والتكنولوجيا الحديثة بالمرج ، المرج ، القليوبية ، مصر. 2- قسم الكيمياء ، كلية العلوم ، جامعة عين شمس ، العباسية ، القاهرة ، 1156 ، مصر.

تم تحضير العديد من أقطاب الكوبالت / الجر افيت بنجاح عبر ترسيب كرونو امبيرومنري للكوبالت من حمام يحتوي على أيون الكوبالت 2الثنائي في وجود أو عدم وجود نركيز مساوي من أيون السيترات وذلك على أقر اص من الجر افيت. وقد تم تقييم كفاءة الأقطاب المحضرة كأقطاب كهربية حفازة يمكنها تحفيز تفاعل تصاعد الأكسجين (OER) ويمكن تلخيص النتائج التي حصلنا عليها فيما يلي: 1 - ـ وجودأيونات السيتر ات في حمام المستخدم لترسيب الكوبلت يفضي إلى أن يتم الترسيب عن طريق تكوين لحظي للعديد من أنوية الكوبلت اثناء ترسيبها من تر اكمها التدريجي (في عدم وجود السبترات)، مما يؤدي إلى تكوين طبقة منتظمة متساوية السمك من معدن الكوبلت على قرص الجر افيت.

r ـ ـ و على ذلك فقد لوحظ أن قطب الكوبالت / الجر افيت الذي تم تحضيره من حمام السيتر ات أظهر نشاطًا كهربيًا حفزيا محسّنًانحو تفاعل تصاعد الأكسجين(OER) مقارنة بالاقطاب المحضرة بدون السبتر ات. r - تم اكساب الأقطاب المحضرة نشاطا تحفيزيا إضافيا وذلك بعمل عدة دورات اضافية من الجهد الدوار في وسط قاعدي من

$$
\text { هيدروكسيد الصوديوم. }
$$

؛ ـ ـ كما تم عمل تقييم لمدى ثبات الأقطاب المحضرة بعمل استقطاب جهد ديناميكي لمدة ساعتين كما توصي الدر اسات المرجعية. و أظهرت نتائج هذا الاختبار ثبات كثافة التيار ثبانًا فائقًا لتفاعل تصاعد الاكسجين في وسط قلوي . 
